$\mathrm{DE}$

M E D I C I N A

T R O P I C A L

$\mathrm{DE}$

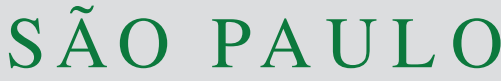

JOURNAL OF THE SÃO PAULO INSTITUTE OF TROPICAL MEDICINE

'Universidade de São Paulo, Faculdade de Medicina, Departamento de Moléstias Infecciosas e Parasitárias, Laboratório de Imunopatologia da Esquistossomose (LIM06), São Paulo, São Paulo, Brazil

2Universidade de São Paulo, Instituto de Medicina Tropical da São Paulo, Laboratório de Helmintologia, São Paulo, São Paulo, Brazil

${ }^{3}$ Universidade de São Paulo, Faculdade de Medicina, Departamento de Gastroenterologia, Laboratório de Gastroenterologia e Hepatologia Tropical, São Paulo, São Paulo, Brazil

${ }^{4}$ Superintendência de Controle de Endemias, São Paulo, São Paulo, Brazil

${ }^{5}$ Hospital A. C. Camargo, Centro Internacional de Pesquisas e Ensino, Laboratório de Genômica Médica, São Paulo, São Paulo, Brazil

'Universidade de São Paulo, Faculdade de Medicina, Hospital das Clínicas, Instituto de Psiquiatria, Laboratório de Neurociências (LIM-27), São Paulo, São Paulo, Brazil

${ }^{7}$ Universidade de São Paulo, Faculdade de Medicina, Departamento de Medicina Preventiva, São Paulo, São Paulo, Brazil

${ }^{8}$ Universidade Fundação Oswaldo Aranha, Volta Redonda, Rio de Janeiro, Brazil

Correspondence to: Maria Cristina Carvalho do Espírito Santo Universidade de São Paulo, Faculdade de Medicina, Departamento de Moléstias Infecciosas e Parasitárias, Laboratório de Imunopatologia da Esquistossomose (LIM-06), Av. Dr. Enéas de Carvalho Aguiar, 470, Cerqueira César, CEP 05403-907, São Paulo, SP, Brazil

Tel: +55 1130618220, +55 1130618220

E-mail: cristinasanto@usp.br

Received: 18 June 2019

Accepted: 10 February 2020

\section{Molecular detection of prepatent Schistosoma mansoni infection in Biomphalaria glabrata snail vectors}

Márcia Oliveira Casotti ${ }^{1}$, Ronaldo Cesar Borges Gryschek ${ }^{1,2}$, Fabiana Martins de Paula ${ }^{(1,2}$, Michele Gomes-Gouvêa ${ }^{2,3}$, João Renato Rebello Pinho ${ }^{2,3}$, Roseli Tuan ${ }^{4}$, Emmanuel Dias-Neto ${ }^{5,6}$, Expedito José de Albuquerque Luna7, Maria Cristina Carvalho do Espírito-Santo ${ }^{1,2,8}$

\section{ABSTRACT}

Approximately 240 million people worldwide are infected by Schistosoma. In Brazil, one of the main intermediate hosts of this parasite is Biomphalaria glabrata snails. The early detection of larval stages in intermediate hosts is an important challenge to public health, but it also represents an opportunity as a new alternative to indicate earlier natural infections before cercariae differentiation and emergence. In this context, we demonstrated that PCR amplification of a $28 \mathrm{~S}$ gene fragment from the parasite does demonstrate $S$. mansoni infection in snails 14 days post infection. This conventional polymerase chain reaction amplified clear bands and was able to detect parasitic infection in the intermediate host B. glabrata under experimental conditions. However, we reinforce that this approach requires deeper investigations and further comparisons to confirm its specificity and sensitivity in earlier time points after miracidia infection. This approach has relevant potential as an effective molecular-based strategy for the monitoring of schistosomiasis transmission.

KEYWORDS: Schistosoma mansoni. Biomphalaria glabrata. Molecular diagnosis. Surveillance. Snail. Vector. Molecular diagnosis. Polymerase Chain Reaction.

\section{INTRODUCTION}

Approximately 240 million people worldwide are infected by Schistosoma trematodes. In Brazil, one of the main intermediate hosts of this parasite is the Biomphalaria glabrata snail ${ }^{1-3}$. The early detection of larval stages in intermediate hosts is an important challenge to public health, but it has the potential to detect positive snail hosts before the emergence of cercariae, thus becoming a new alternative to detect intramollusc forms ${ }^{4,5}$, revealing reliable parasite prevalence rates. The objective of this study is to evaluate the prepatent detection of $S$. mansoni DNA in B. glabrata snails using the polymerase chain reaction (PCR) 14 days after snails exposed to miracidia. Furthermore, we aimed to standardize the entire process, evaluating the specificity of the primers in two groups of snails.

\section{MATERIAL AND METHODS}

\section{Laboratory maintenance of the S. mansoni experimental cycle}

The laboratory cycle of $S$. mansoni has been implemented more than 30 years ago at the Instituto de Medicina Tropical de Sao Paulo, using a S. mansoni strain 
obtained in Belo Horizonte, Minas Gerais, Brazil (BH strain), as well as a B. glabrata strain (GIDE), collected in Campinas, Sao Paulo, Brazil.

Since the beginning, the $S$. mansoni cycle was maintained through periodic infections of hamsters (Mesocricetus auratus) and B. glabrata snails at the Laboratory of Schistosomiasis Immunopathology (LIM-06). Hamsters were kept in the animal house of of Instituto de Medicina Tropical de Sao Paulo, Universidade de Sao Paulo, Brazil, and all the experiments followed the Ethical Principles in Animal Experimentation of the Brazilian College of Animal Experimentation (CEP IMT2011/096).

\section{Infection of B. glabrata by S. mansoni}

Approximately 30 miracidia were obtained from a laboratory cycle of $S$. mansoni and were counted on Kline plates. Ten B. glabrata $(\mathrm{BH})$ snails were infected and compared to ten non-infected snails to evaluate the primers' specificity to $S$. mansoni DNA, and the presence of spurious non-specific bands derived from the snail host. A total of ten B. glabrata snails were exposed to approximately 30 miracidia and had their head-foot portions removed 14 days after this exposure. DNA was extracted soon after removing the snail's head and foot, using the QIAamp ${ }^{\circledast}$ DNA Mini Kit (QIAGEN Inc., Hilden, USA), following the manufacturer's instructions. DNA was quantified in a Nanodrop DR 1000 Spectrophotometer V3.8 ${ }^{\circledR}$ (Thermo Fisher Scientific, Delaware,USA).

\section{Amplification of S. mansoni DNA from primary sporocysts}

PCR amplification was performed with the following $S$. mansoni-specific primers: $\mathrm{SmF}$ (5'-GAGATCAAGTGTGACAGTTTTGC-3') and SmR (5'-25ACAGTGCGCGC GTCGTAAGC-3'), targeting the parasite 28S rDNA, yielding a 350-base pairs amplicon, as previously described by Sandoval et al. ${ }^{6}$.

PCR amplifications were performed in a final volume of $25 \mu \mathrm{L}$ containing $2.5 \mu \mathrm{L} 10 \mathrm{X}$ reaction buffer, $3 \mathrm{mM}$ $\mathrm{MgCl}_{2}, 0.5 \mathrm{mM}$ of each dNTP, $0.2 \mathrm{mM}$ of each primer, $2.5 \mathrm{U}$ of Platinum Taq DNA polymerase (Invitrogen TM Life Technologies, Carlsbad, CA, USA) and $1 \mu \mathrm{L}$ of DNA. The amplification consisted of 35 cycles, as follows: $94^{\circ} \mathrm{C}$ for $20 \mathrm{~s}, 65{ }^{\circ} \mathrm{C}$ for $20 \mathrm{~s}$, and $72{ }^{\circ} \mathrm{C}$ for $30 \mathrm{~s}$. Amplicons were evaluated in $2 \%$ SYBR-safe-stained agarose gels and visualized under UV lights. DNA derived from adult S. mansoni worms (90 ng) and ultrapure Milli-Q water were used as positive and negative controls, respectively.
The possibility of samples contamination was minimized by the physical separation of rooms for DNA extraction and DNA amplification and by using laminar flow hoods, ultraviolet light chambers, and sterile, disposable laboratory materials including pipette filter tips.

\section{RESULTS AND DISCUSSION}

This study evaluated infection in the intermediate host by using a molecular biology technique.The visualization of the expected size amplicons, corresponding to Schistosoma mansoni $28 \mathrm{~S}$ rDNA gene showed single amplicons for the positive control as well as for the infected snails, suggesting its specificity to the parasite DNA; in addition, no bands were seen when DNA from the non-infected snails or water were used as templates.

The amplification products of $S$. mansoni DNA extracted together with DNA from the snail host showed clear and specific bands 14 days after miracidia infection, indicating that the lower mass of sporocyst-derived DNA was enough to provide positive results (Figure 1).

Detection of Schistosoma DNA in the prepatent period, with different parasite loads, was first described by JannottiPassos et al. in $1997^{5}$, using a tandem repeated sequence of the parasite genome as the amplification target region. Subsequently, the same group reported the molecular identification of the parasite, targeting a mitochondrial DNA repeat in $S$. mansoni that allowed its detection in infected B. glabrata, with absence of non-specific (spurious) bands. This result points to the selectivity and specificity of this marker in the previous identification of infected snail hosts ${ }^{4,7}$. Since then, other studies aimed at performing the molecular diagnosis of infection in intermediate hosts have been developed and employed the loop-mediated isothermal amplification $^{4,5,8}$.

Currently, the Brazilian surveillance control program recommends a conventional method to diagnose $S$. mansoni infections, in which snails suspected of being infected are exposed to light to stimulate cercariae release ${ }^{9}$. Cercariae are usually observed approximately 40 days after miracidia infection, at the end of this parasitic asexual cycle ${ }^{3}$.

The implementation of sensitive diagnostic tools to monitor the parasitic infection status in humans, mammalian reservoirs and intermediate hosts is part of the strategies discussed and recommended by $\mathrm{WHO}^{10}$.

Thus, the combination between traditional and molecular methods will help to improve the malacological surveillance of Schistosomiasis mansoni, especially in areas of low endemicity.

This study corroborates this point of view by improving diagnosis in the prepatent stage of infection in snails. 


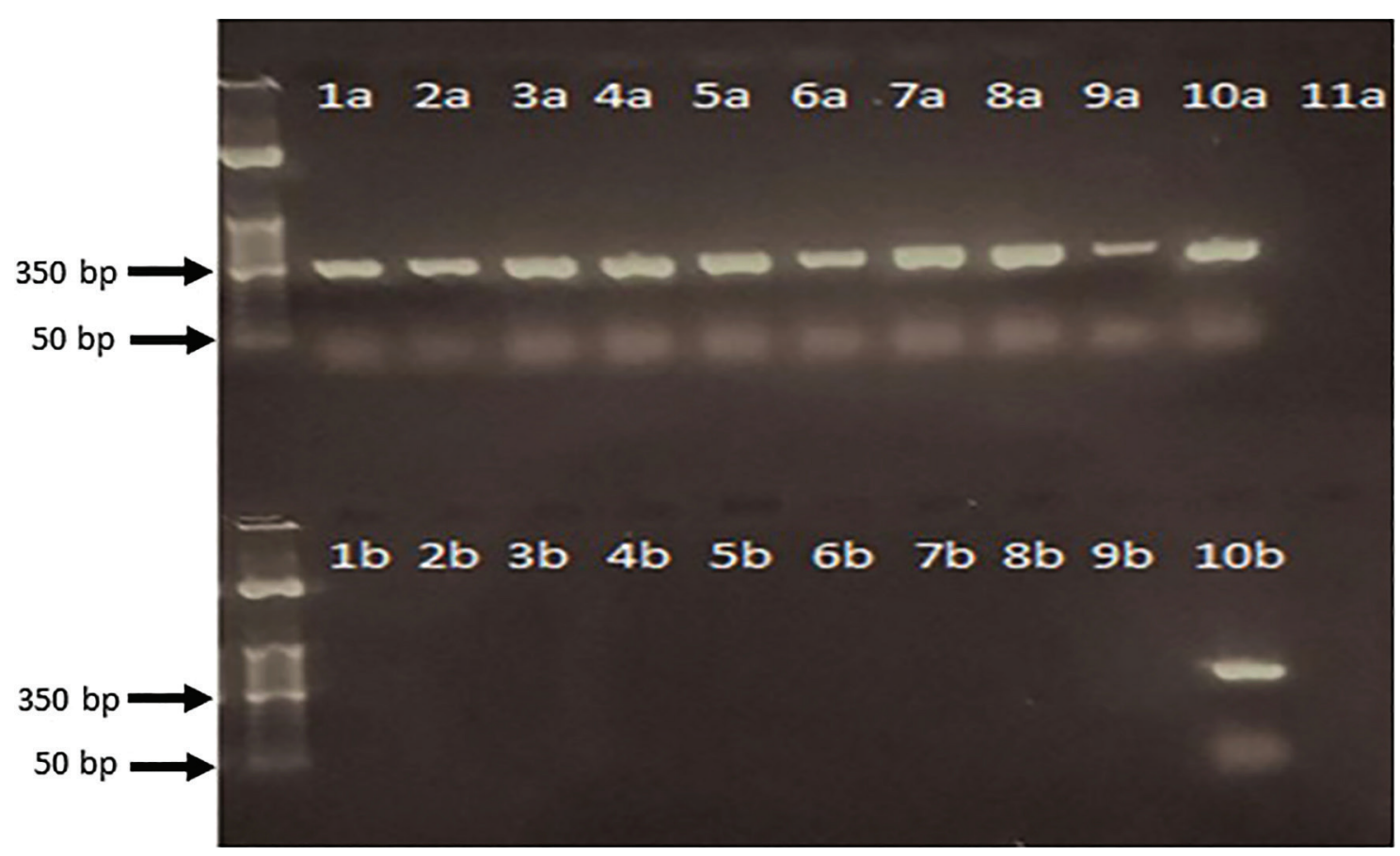

Figure 1 - The $350 \mathrm{bp}$ amplification product from S. mansoni 28S rDNA gene using as template, DNA extracted from $B$. glabrata snails 14 days after their exposure to $\sim 30$ miracidia (1a to 10a) and B. glabrata snails not exposed to experimental infection (1b to 9b). 11a: negative control (ultrapure Milli-Q sterile water); 10b: positive control (DNA from adult S. mansoni worms). Molecular weight marker: 50 bp DNA ladder (Invitrogen TM Life Technologies Carlsbad, CA, USA).

Schistosomiasis is a chronic infection that may not progress to a severe form but can trigger debilitating sequelae that are secondary to parasitism ${ }^{11}$. Therefore, surveillance is critical in endemic areas. Nevertheless, considering that most infected snails can die during the vector surveillance process and that conventional techniques are efficient only for live snails after the completion of the period necessary for cercariae emergence, the prevalence of infection can be underestimated. These factors emphasize the need of a correct diagnosis prior to this stage, especially in areas of low endemicity, in which infections generally present low parasite loads $\mathrm{s}^{5,12,13}$.

It is known that $B$. glabrata snails are the most susceptible intermediate host of this trematode compared to other natural snail hosts, and the implementation of sensitive diagnostics is a crucial and valuable tool to monitor parasitic infection status in humans, mammalian reservoirs, and intermediate snail hosts.

\section{CONCLUSION}

The results presented here reinforce that conventional PCR can be used to detect the presence of $S$. mansoni infection in the prepatent period, suggesting that this methodology is a sensitive and specific tool that is able to detect the parasite infection in intermediate hosts approximately 15 days before the traditional techniques.

\section{ACKNOWLEDGMENTS}

We appreciate Ms. Maria Cristina Conceição de Mello (LIM-06, FMUSP) for her technical assistance concerning the maintenance of the $S$. mansoni biological cycle.

\section{AUTHORS' CONTRIBUTIONS}

Conceived and designed the study: MCCES, MOC, EJAL, RT, MGG, RCBG; contributed with analyses/tools: FMP, JRRP; wrote the paper: MCCES, MOC. All authors have read and approved the manuscript.

\section{CONFLICT OF INTERESTS}

The authors have declared that there is no conflict of interests.

\section{FINANCIAL SUPPORT}

This study was funded by the Research Support Foundation of Sao Paulo State (FAPESP, N 2016/237420), which enabled the acquisition of material and structural resources, in addition to publication support. 


\section{REFERENCES}

1. Colley DG, Bustinduy AL, Secor WE, King CH. Human schistosomiasis. Lancet. 2014;383:2253-64.

2. Brasil. Ministério da Saúde. Secretaria de Vigilância em Saúde. Departamento de Vigilância das Doenças Transmissíveis. Plano integrado de ações estratégicas de eliminação da hanseníase, filariose, esquistossomose e oncocercose como problema de saúde pública, tracoma como causa de cegueira e controle das geohelmintíases: plano de ação 2011-2015. Brasília: Ministério da Saúde; 2012. [cited 2020 Feb 10]. Available from: http:// bvsms.saude.gov.br/bvs/publicacoes/plano_integrado_acoes_ estrategicas_2011_2015.pdf

3. World Health Organization. Sixty-Sixth World Health Assembly: agenda item 16.2: neglected tropical diseases. Geneva: WHO; 2013. [cited 2020 Feb 10]. Available from: https://www.who. int/neglected_diseases/mediacentre/WHA_66.12_Eng.pdf

4. Gandasegui J, Fernández-Soto P, Hernández-Goenaga J, LópezAbán J, Vicente B, Muro A. Biompha-LAMP: a new rapid loop-mediated isothermal amplification assay for detecting Schistosoma mansoni in Biomphalaria glabrata snail host. PLoS Negl Trop Dis. 2016;10:e0005225.

5. Jannotti-Passos LK, Vidigal TH, Dias-Neto E, Pena SD, Simpson AJ, Dutra WO, et al. PCR amplification of the mitochondrial DNA minisatellite region to detect Schistosoma mansoni infection in Biomphalaria glabrata snails. J Parasitol. 1997;83:395-9.

6. Sandoval N, Siles-Lucas M, Lopez Aban J, Pérez-Arellano JL, Gárate T, Muro A. Schistosoma mansoni: a diagnostic approach to detect acute schistosomiasis infection in a murine model by PCR. Exp Parasitol. 2006;114:84-8.
7. Allienne JF, Théron A, Gourbal B. Recovery of primary sporocysts in vivo in the Schistosoma mansoni/Biomphalaria glabrata model using a simple fixation method suitable for extraction of genomic DNA and RNA. Exp Parasitol. 2011;129:11-6.

8. Hamburger J, He-Na, Xin XY, Ramzy RM, Jourdane J, Ruppel A. A polymerase chain reaction assay for detecting snails infected with bilharzia parasites (Schistosoma mansoni) from very early prepatency. Am J Trop Med Hyg. 1998;59:872-6.

9. Brasil. Ministério da Saúde. Secretaria de Vigilância em Saúde. Departamento de Vigilância Epidemiológica. Vigilância e controle de moluscos de importância epidemiológica. $2^{\mathrm{a}}$ ed. Brasília: Ministério da Saúde; 2008. [cited 2020 Feb 10]. Available from: https://portalarquivos2.saude.gov.br/images/ pdf/2015/agosto/14/vigilancia-controle-moluscos-importepidemio-2ed.pdf

10. World Health Organization. Sixty-Fifth World Health Assembly: Geneva, 21-26 May 2012: resolutions and decisions, annexes. Geneva: WHO; 2012. [cited 2020 Feb 10. Available from: http://apps.who.int/gb/DGNP/pdf_files/A65_REC1-en.pdf

11. Chitsulo L, Engels D, Montresor A, Savioli L. The global status of schistosomiasis and its control. Acta Trop. 2000;77:41-51.

12. Guaraldo AM, Magalhães LA, Rangel HA, Pareja G. Evolução dos esporocistos de Schistosoma mansoni Sambon, 1907 em Biomphalaria glabrata (Say, 1818) e Biomphalaria tenagophila (D’Orbigny, 1835). Rev Saude Publica. 1981;15:436-48.

13. Martins-Melo FR, Pinheiro MC, Ramos Jr AN, Alencar CH, Bezerra FS, Heukelbach J. Trends in schistosomiasis-related mortality in Brazil, 2000-2011. Int J Parasitol. 2014;44:105562. 